\title{
The Effect of Training and Job Satisfaction on Employee Engagement and Performance of Millennial Generation Employees of PT Midi Utama Indonesia Tbk in Makassar
}

\author{
Sri Rizky Ramadhany ${ }^{1}$, Muhammad Idrus Taba ${ }^{2}$, Fauziah $\mathrm{Umar}^{3}$ \\ ${ }^{1}$ Master of Management Student, Faculty of Economics and Business, Hasanuddin University; \\ ${ }^{2}$ Lecturers in Management, Faculty of Economics and Business, Hasanuddin University; \\ ${ }^{3}$ Lecturers in Management, Faculty of Economics and Business, Hasanuddin University;
}

\begin{abstract}
This study aims to determine the effect of training, job satisfaction and employee engagement on millennial generation performance at PT Midi Utama Indonesia in Makassar. Training and job satisfaction act as independent variables, performance as the dependent variable and employee engagement as an intervening variable. This research is a quantitative study using path analysis. Subjects in this study were 52 store employees of Alfa Midi. The data in this study were obtained by questionnaire and then processed using SPSS. The results showed that training had no significant effect on employee engagement, job satisfaction had a significant effect on employee engagement, employee engagement had a significant effect on performance, training had no significant effect on performance, job satisfaction had no effect on performance, training had no significant effect on employee performance through variables employee engagement, and job satisfaction significantly influence employee performance through employee engagement variables.
\end{abstract}

Keywords:- Training, Job Satisfaction, Employee Engagement, Employee Performance.

\section{INTRODUCTION}

Based on the results of the Central Statistics Agency survey (in Purnami, 2019) the total workforce in Indonesia reached more than $160,369,800$ people with composition based on generation as follows Millennial Generation (born 1986-2000) as many as $62,570,920$ (39.02\%), while Generation $\mathrm{X}$ is $69,003,270(43.03 \%)$ and Baby Boomer Generation is 28,795,610 (17.96\%). In 2016, Dale Carnegie Indonesia conducted a survey in six major cities of Jakarta, Surabaya, Bandung, Makassar, Balikpapan, and Medan of 1200 employees on Employee Management Among Millennials, showing that only $25 \%$ of the millennial workforce was fully engaged with the company they worked for, $9 \%$ disengaged and $66 \%$ partially engaged. 1 out of 4 millennials engaged in $64 \%$ said they would survive for at least 1 year while $60 \%$ employees were planning to resign (Purnami, 2019).
In 2018 the population included on the workforce in Makassar was 3,988,029 peoples (gosulsel.com, 2018). In 2030, the productive age population in Indonesia is estimated to reach 201.8 million people or $68 \%$ of Indonesia's population (Badan Pusat Statistik, 2013). The millennial generation is the generation born in 1980-2000, currently aged 18-38 years. This generation has another name for the millennials or $\mathrm{Y}$ generation (Deal and Levenson, 2016). Millennial generation is born and grows in the era of technological development and has the ability to use technology better than the previous generation. This ability makes them easy to find information, more creative and innovative.

Millennials are very easy to decide to change jobs if they feel a little uncomfortable with their work. In addition, they are very picky if they want to apply for a job. According to a survey also conducted by the JobStreet website, from a job opening, this generation is very concerned about the benefits of working in a company, including facilities and comfort of work. In addition to high salaries, millennial generation also wants the company where they work can provide a variety of training and selfdevelopment (CNN Indonesia, 2016).

Employee engagement is one way to make employees have high loyalty, as Macey and Schneider (in Muliawan, Perizade \& Cahyadi, 2018) say that employee engagement makes employees have higher loyalty, thereby reducing the desire to leave the company voluntarily. Employee engagement according to Robbins and Judge (2015) is an employee's individual involvement, satisfaction, and enthusiasm to do his job. Robinson et. al., (2004) defines employee engagement as a positive attitude that employees have towards the company where they work and the values that exist within the company.

Employee engagement is also important to see the effect on performance. There are many previous studies (Muliawan et al, 2018) that show employee engagement has an influence on performance. Effective performance is the key to good productivity, on an individual or organizational scale, so employees are expected to be able to show performance as expected by the company or organization. 
Schmitt (2011) defines performance as the contribution of each worker to his organization. This contribution can be in the form of outputs that are supportive of the organization's goals, or that have a negative impact on the organization. So that performance is an aspect that really needs to be considered considering employee performance can be an obstacle to effective productivity for the organization, for example with a lot of absenteeism, abuse of facilities, or lazing while working.

Training is one way to improve employee performance. Companies need to manage training programs more effectively to get many benefits. This is necessary because the improvement in the abilities, knowledge and skills of talented employees is proven to be a source of competitive advantage (Ronald in Sulaefi, 2017). Training and development are strategic tools that are indispensable for improving employee and organizational performance. For this reason, the budget for training needs to be increased every year, because it is believed to get competitive advantages (Tjahjono, 2005; Falola, et.al in Sulaefi, 2017).

Another factor that acts as a driver of employee engagement is job satisfaction (Robinson et al. In Robertson \& Markwick, 2009). Robbins (in Pratiwi \& Himam, 2014) said that the term job satisfaction refers to a person's general attitude towards his job. Someone with a high level of job satisfaction shows a positive attitude towards his job, while someone who is dissatisfied with his job shows a negative attitude towards the job. According to job satisfaction is also said to increase employee motivation at work, involvement in work, employee commitment to the organization, increased productivity and performance and others (Kreitner \& Kinicki in Mangundjaya, 2012).

This research was written based on the phenomenon that occurred at PT Midi Utama Tbk Indonesia Makassar. PT Midi Utama Indonesia tbk is one of retail company that has minimarket with Alfa Midi brand which has 52 outlets in Makassar. This company is one of the companies that the most demand by millennials. This is evidenced by the employees who work in this company are dominated by employees aged 20 to 30 years old. Many methods are carried out by human capital teams PT. Midi Utama Indonesia to maintain them employees to engaged with company, have high work motivation and provide maximum contribution to the company. PT. Midi Utama Indonesia makes various efforts such as providing equal opportunities to all employees in order to be able to promote positions and various other efforts in the hope that employees can engage with the company and involve their employees in various types of training so that employees have high initiative in working. Many studies have shown that an important way to improve employee performance is to focus on developing employee engagement. Previous research conducted by Dayona \& Rinawati (2016) states that training and career development are equally significant both directly and indirectly on employee engagement. Another factor that acts as a driver of employee engagement is job satisfaction (Robinson et al. In Robertson \& Markwick, 2009).

\section{THEORETICAL BASIS}

\section{A. Training}

Mondy (2008) explains that training and development are at the heart of ongoing efforts to improve employee competency and organizational performance. Training gives learners the knowledge and skills needed for the current job. Whereas development involves learning that goes beyond current work and has a more long-term focus. Training and development activities have the potential to align employees with company strategies. Handoko (2012) states that training (training) is intended to improve the mastery of various skills and technical implementation of specific, detailed and routine work. In this case, the training prepares employees to do the work now. Training and development have an important role to improve the performance of employees to improve quality human resources. At the beginning of the job training aims to improve the competencies that must be owned by technical personnel, which are requirements set by the company. Advanced training is intended to increase competence to a higher level of expertise in their field or adjust if there is new technology that must be handled in their field or to form new capabilities if they move their field of work (Lolowang, Adolfina \& Lumintang, 2016)

\section{B. Job Satisfaction}

Hoppock (in Sijabat, 2011) states that job satisfaction is a combination of psychological factors and work environment that results in someone saying they are satisfied with their work. Job satisfaction is an expression of one's feelings or attitudes towards work, towards promotional opportunities, relationships with coworkers, supervision and feelings of satisfaction with the work itself (Titisari, in Sari \& Susilo, 2018). Job satisfaction reflects nature more than behavior. Handoko (in Sari \& Susilo, 2018) explains that job satisfaction is a pleasant emotional state when employees carry out their respective jobs.

Job satisfaction refers to the general attitude of an individual towards his job. Keith Davis (in Indy \& Handoyo, 2013) argues: "Job satisfaction is the favorability or unfavorability with which employees view their work". Job satisfaction is a feeling of supporting or not supporting experienced by employees in doing their jobs. Meanwhile, according to Wexley and Yulk (in Pratiwi \& Himam, 2014) job satisfaction is "the way an employee feels about his or her job". This means that job satisfaction is one's feeling towards his job as a positive emotional state.

\section{Employee Engagement}

Employee engagement is defined as a positive attitude, full of meaning, and motivation, which is characterized by vigor, dedication, and absorption. Vigor is characterized by high levels of energy, resilience, the desire to try, and not give up in facing challenges. Dedication is characterized by feeling valued, enthusiastic, inspiring, valuable and challenging. Absorption is characterized by 
full concentration of an assignment (Schaufeli \& Bakker, 2004). Employee engagement is characterized as a sense of commitment, has a great desire and enthusiasm that embodies efforts to a higher level, continues to work hard with any difficulty of tasks beyond what is expected and has initiative.

\section{Employee Performance}

Performance is defined as the total value expected by an organization from a set of behaviors that individuals show over a certain period of time. An important concept of this definition is that performance is behavior. More specifically, the behavior is a combination of several different behaviors, which appear in a span of time. The second important concept is that behavior which is a performance is an expected value from the organization (Borman et al, 2003). So for example if the employee exhibits a behavior to dispose of waste, and that is not behavior in the form of expected value from the organization, then the behavior of disposing of waste is not performance. Based on the definitions revealed above, the definition of performance is the behavior of individuals while working within a certain period of time that is relevant to the objectives of the organization, both in the form of productive and counterproductive behavior. This performance is seen not only from the actions of individuals at work, but how the evaluation and assessment process carried out by the surrounding environment. This performance can also be seen by the individual himself whose results constitute a self evaluation of performance. Individuals evaluate themselves in terms of how productive and counterproductive their behavior is at work.

\section{RESULT}

The population in this study were employees of PT Midi Utama Indonesia Makassar who worked as crew and head stores in 10 PT Midi Utama Indonesia Makassar outlets which determined by the company. From the data obtained from the personnel department there are 106 employees. The sample in this study were determined using the Slovin method so in this study the number of samples were 52 employees. The researcher distributes the questionnaire and then takes the questionnaire back.

\section{A. Path Analysis Model 1}

In the path analysis model 1 calculates the value of the direct influence of training (X1) and job satisfaction (X2) to employee engagement (Y). In the path analysis of model 1, training and job satisfaction act as exogenous and employee engagement acts as an exogenous variable.

\begin{tabular}{|c|c|c|c|c|}
\hline Model & $\mathrm{R}$ & R Square & $\begin{array}{c}\text { Adjusted R } \\
\text { Square }\end{array}$ & $\begin{array}{c}\text { Std. Error of } \\
\text { the Estimate }\end{array}$ \\
\hline 1 & $.468^{\mathrm{a}}$ & .219 & .187 & 6.71812 \\
\hline \multicolumn{4}{|c|}{ a. Predictors: (Constant), Job Satisfaction, Training } \\
\hline
\end{tabular}

Table 1
The model of the multiple linear regression equation model 1 obtained is as follows:

$$
Y=0,182 X 1+0,356 X 2+e 1
$$

Based on table of the Summary Model above, the $\mathrm{R}$ square value is 0.219 . This shows that the contribution of the influence of $\mathrm{X} 1, \mathrm{X} 2$ to $\mathrm{Y}$ is $21.9 \%$ and the remaining $78.1 \%$ is contributed by other variables not included in this study. Meanwhile, the value of e1 is obtained from $\sqrt{ }$ (1$0,219)$. The result, $\mathrm{e} 1=0.883$.

The significance value of the three variables, namely $\mathrm{X} 1=0,211, \mathrm{X} 2=0.0117$. These results provide the conclusion that Regression Model I, namely the variables $\mathrm{X} 1$ did not significant effect on $\mathrm{Y}$ and $\mathrm{X} 2$ has a significant effect on $\mathrm{Y}$.

\section{B. Path Analysis Model 2}

In the path analysis model 2 calculates the value of the direct influence of employee engagement (Y) to employee performance $(\mathrm{Z})$. In the path analysis of model 2, employee engagement act as an exogenous and employee performance acts as an exogenous variable.

\begin{tabular}{|c|c|c|c|c|}
\hline Model & $\mathrm{R}$ & R Square & $\begin{array}{c}\text { Adjusted R } \\
\text { Square }\end{array}$ & $\begin{array}{c}\text { Std. Error of } \\
\text { the Estimate }\end{array}$ \\
\hline 1 & $.396^{\mathrm{a}}$ & .157 & .139 & 8.89755 \\
\hline \multicolumn{3}{|c|}{ a. Predictors: (Constant), Employee engagement } \\
\hline
\end{tabular}

Table 2

The model of the multiple linear regression equation model 2 obtained is as follows:

$$
Y=0,396 \mathrm{Y} 1+e 2
$$

Based on table of the Summary Model above, the R square value is 0.157 . This shows that the contribution of the influence $\mathrm{Y}$ to $\mathrm{Z}$ is $15 \%$ and the remaining $85 \%$ is contributed by other variables not included in this study. Meanwhile, the value of $\mathrm{e} 2$ is obtained from $\sqrt{ }(1-0,396)$. The result, $\mathrm{e} 2=0.777$.

The significance value of the three variables, namely $\mathrm{Y}=0.0004$. These results provide the conclusion that Regression Model 2, namely the variables $\mathrm{Y}$ has a significant effect on $\mathrm{Z}$.

\section{Path Analysis Model 3}

In the path analysis model 3 calculates the value of the direct influence of training (X1), job satisfaction (X2) and employee engagement $(\mathrm{Y})$ to employee performance $(\mathrm{Z})$. In the path analysis of model 3, training, job satisfaction and employee engagement act as an exogenous and employee performance acts as an exogenous variable. 


\begin{tabular}{|c|c|c|c|c|}
\hline Model & $\mathrm{R}$ & R Square & $\begin{array}{c}\text { Adjusted R } \\
\text { Square }\end{array}$ & $\begin{array}{c}\text { Std. Error of } \\
\text { the Estimate }\end{array}$ \\
\hline 1 & $.714^{\mathrm{a}}$ & .510 & .478 & 6.92702 \\
\hline \multicolumn{4}{|c|}{ a. Predictors: (Constant), Job satisfaction, Employee } \\
engagement, Training \\
\hline
\end{tabular}
Table 3

The model of the multiple linear regression equation model 3 obtained is as follows:

$$
\mathrm{Z}=0,122 X 1+0,604 X 2+0,088 \mathrm{Y} 1+e 3
$$

Based on table of the Summary Model above, the $\mathrm{R}$ square value is 0.510 . This shows that the contribution of the influence $\mathrm{X} 1, \mathrm{X} 2$ and $\mathrm{Y}$ to $\mathrm{Z}$ is $51 \%$ and the remaining $49 \%$ is contributed by other variables not included in this study. Meanwhile, the value of e3 is obtained from $\sqrt{ }$ (1$0,510)$. The result, e $3=0.7$.

The significance value of the three variables, namely $\mathrm{X} 1=0.302, \mathrm{X} 2=0.000$ and $\mathrm{Y}=0.0004$. These results provide the conclusion that Regression Model 2, namely the variables $\mathrm{X} 1$ did not significant effect and $\mathrm{X} 2$ and $\mathrm{Y}$ has a significant effect on $\mathrm{Z}$.

\section{Hypothesis Test}

$>$ Analysis of the Effects of X1 on Y : Based on the analysis results, the significance value of $\mathrm{X} 1$ is $0.21>$ 0.05 . So it can be concluded that there is no significant effect on the $\mathrm{X} 1$ variable on $\mathrm{Y}$.

$>$ Analysis of the effect of $\mathrm{X} 2$ on $\mathrm{Y}$ : Based on the analysis of the significance value of $\mathrm{X} 2$ is $0.01<0.050$. Based on these results it can be concluded that there is an insignificant direct effect of $\mathrm{X} 2$ on $\mathrm{Y}$.

$>$ Analysis of the effect of $\mathrm{X} 1$ on $\mathrm{Z}$ : Based on the results of the analysis result, the significance value of $\mathrm{X} 1$ is $0.30<0.05$. So it can be concluded that there is no significant effect on the $\mathrm{X} 2$ variable on $\mathrm{Z}$.

$>$ Analysis of the effect of X2 on Z : Based on the results of the analysis result, the significance value of $\mathrm{X} 2$ is $0.00<0.05$. Based on these results it can be concluded that there is an insignificant direct effect of $\mathrm{X} 2$ on $\mathrm{Z}$.

$>$ Analysis of the effect of $\mathrm{Y}$ on $\mathrm{Z}$ : based on the results of the analysis above, the significance value of $\mathrm{Y}$ is $0,00<$ 0.05 . So it can be concluded that there is a significant direct effect of $\mathrm{Y}$ on $\mathrm{Z}$.

$>$ Analysis of the effect of X1 through $\mathrm{Y}$ on $\mathrm{Z}$ : Based on the above results it is known that the direct effect of $\mathrm{X} 1$ given on $\mathrm{Y}$ is 0.021 . While the indirect effect of $\mathrm{X} 1$ through $\mathrm{Y}$ on $\mathrm{Z}$ is 0.016 . This value is obtained from the multiplication between the value of beta $X 1$ against $Y$ with the value of beta $\mathrm{Y}$ against $\mathrm{Z}$, which is $0.182 \mathrm{x}$ $0.088=0.016$. So that the total effect given $\mathrm{X} 1$ on $\mathrm{Z}$ is the direct effect of the indirect effect, namely: $0.211+$ $0.016=0.271$. Based on these results it is known that the value of the indirect effect 0.016 is smaller than the value of the direct effect 0.211 . This shows that indirectly $\mathrm{X} 1$ through $\mathrm{Y}$ did not has an insignificant effect on $\mathrm{Z}$.

$>$ Analysis of the effect of X2 through Y on Z: Based on the above results it is known that the direct effect of $X 1$ given on $\mathrm{Y}$ is 0.017 . While the indirect effect of $\mathrm{X} 2$ through $\mathrm{Y}$ on $\mathrm{Z}$ is 0.031 . This value is obtained from the multiplication between the value of beta $X 2$ against $Y$ with the value of beta $\mathrm{Y}$ against $\mathrm{Z}$, which is $0.356 \mathrm{x}$ $0.088=0.031$. So that the total effect given $\mathrm{X} 2$ on $\mathrm{Z}$ is the direct effect of the indirect effect, namely: $0.017+$ $0.031=0.048$. Based on these results it is known that the value of the indirect effect 0.031 is greater than the value of the direct effect 0.017. This shows that indirectly X2 through $\mathrm{Y}$ has an insignificant effect on $\mathrm{Z}$.

\section{CONCLUSION}

Training did not has significant effect to employee engagement. Training is another important dimension which is to be considered in the process of engaging employees since it helps the employees to concentrate on a focused work dimension. This is happened because employees said the training was not very effective for them. They need training which can make them more creative at work. Training improves service accuracy and thereby impacts service performance and employee engagement. When the employee undergoes training and learning development programmes, them confidence builds up in the area of training that motivates them to be more engaged in their job. Dessler (2014) revealed that companies provide training for their employees because they view employees as capital (capital) which plays an important role for the progress of their company so that it is given proper treatment which is then expected that the employee can engage with his company. This theory is in line with previous research conducted by Dayona \& Rinawati (2016) states that training and career development are equally significant both directly and indirectly on employee engagement. This shows that the better training and career development, the stronger employee engagement and vice versa the less training and career development, the more fragile employee engagement.

$>$ Job satisfaction has significant effect to employee engagement. Job satisfaction is one of employee engagement driver. Job satisfaction illustrates the extent to which an employee likes his job and creates a positive attitude towards the job. Employees who are satisfied with their work will be more active in their work and consider leaving the organization where they work. Type of work, benefits, recognition, coworkers, fair treatment, company union, support and management performance can increase employee job satisfaction which will also encourage employee engagement. Employees who feel engaged will do a good job. The results of this study also support the theory developed by Garg and Kumar (2012) which states that job satisfaction is the driving force for employee engagement. It was explained that employees who were satisfied with their work would be more active in their work and consider leaving the organization where they worked. Garg and Kumar (2012) explain the effect of job satisfaction on employee engagement supported by the findings of the analysis of the factors which state that clarity related to 
work and awards from superiors are also important contributors in the creation of employee engagement.

$>$ Training did not has significant effect to employee performance. This happened because employees feel that the training provided is not appropriate to their work. According to them, this is due to the lack of training materials and the lack of training provided by the company in supporting the implementation of employee duties. This is different from the results of previous studies which revealed the fact that the implementation of employee training and employee performance on the CV. Cibalung Happy Land Bogor is quite good. Tie the results of hypothesis testing there is a real relationship between employee training and employee performance. The results of the regression hypothesis test can be concluded that the training has an effect on performance. A positive $t$ value means that the effect is positive, ie if the training increases, the performance will increase (Yusnita \& Fadhil, 2015). Previous research on training and development was carried out by Irene Ferguson laing (bsc. Admin. Hrm) (2009) in her research entitled The Impact Of Training And Development On Worker Performance and Productivity in Public Sector Organizations: A Case Study Of Ghana Ports and Harbors Authority. The research also states that through training and development, employees are effective tools for achieving both personal and organizational success.

> Job satisfaction has significant effect to employee performance. Every employee in a company needs to get satisfaction at work which can also have an impact on improving employee performance. Good job satisfaction from the employees will improve employee performance. If employees satisfied with their work, they will likes and motivated to carry out their work and get high performance. Good employee performance is indicated by the presence good quality work in completing every job given by the leader in a timely manner determined and can achieve each target that has been determined by the company. This is consistent with previous research conducted by Wijaya (2018) which proves the effect of job satisfaction on employee performance is significant. This means that the test results prove that job satisfaction with employee performance at CV Bukit Sanomas is proven. The results of this study can be seen that with good job satisfaction from the company will improve employee performance. The results of this study are in line with research Saputra, Bagia, Yulianthini (2016) which states that if an employee's satisfaction increases, it will have a positive impact on performance.

$>$ Employee engagement has significant effect to employee performance. Employee engagement is the ability to contribute company succes, which is employees willing to work more harder to complete their work with all of them mind and energy even must working overtime. This is clearly influential employee performance. The results of this study support the theory of Anitha J. (2014) namely "Determinants of employee engagement and their impact on employee performance" which states that employee engagement has a positive and significant effect on employee performance. In addition, Robinson et al. (2006) states that employee performance is one of the things that results from the creation of high employee engagement and employees who have strong links with the company will improve performance in their work for the benefit of the company.

$>$ Training had no significant effect on employee performance through variables employee engagement.

$>$ Job satisfaction significantly influence employee performance through employee engagement variables.

\section{REFERENCES}

[1]. Abraham, S. (2012). Job satisfaction as an antecedent to employee engagement. SIES Journal of Management, 8(2).

[2]. Albrecht, S. L., (2010). Research and Practice. Handbook of Employee Engagement Perspective, Issues. UK: MGP Books Group.

[3]. Aziri, B. (2011). Job satisfaction: A literature review. Management research and practice, 3(4).

[4]. Bakker,. B., Leiter, M. P. (2010). Work Engagement: A Handbook of Essential Theory and Research. New York: Psychology Press.

[5]. Borman, W.C., Ilgen, D.R., Klimoski, R. (2003). Handbook of Psychology. Industrial and Organizational Psychology 12, 39-52. John Wiley \& Sons, Inc.: New jersey.

[6]. Cania, L. (2016). The impact of strategic human resource management on organizational performance. Economia. Seria Management, 17(2).

[7]. Dayona, G., \& Rinawati, N. (2016). Pengaruh Pelatihan Dan Pengembangan Karir Terhadap Employee engagement Di PT Andalan Finance Indonesia. E-Jurnal STIE INABA, 15(2), 1-23.

[8]. Deal, J., \& Levenson, A. (2016). What millennials want from work: How to maximize engagement in today's workforce. United States of America: McGraw-Hill Education

[9]. Deloitte. (2016). The 2016 Deloitte Millennial Survey. United Kingdom: Deloitte.

[10]. Dessler, Gary. 2014. Manajemen Sumber Daya Manusia. Edisi Kesepuluh. Jakarta Barat. PT Indeks

[11]. Endres, G. M., Smoak, L. M. (2008), The Human Resource Craze: Human Performance Improvement and Employee Engagement. Organization Development Journal.

[12]. Hewitt, A. (2012). 2012 Trends in global employee engagement. Aon Corporation.

[13]. Indy, H. H., \& Handoyo, S. (2013). Hubungan kepuasan kerja dengan motivasi kerja pada karyawan bank btpn madiun. Jurnal Psikologi Industri dan Organisasi, 2(2), 1-5.

[14]. Karangan, C. R. (2015). Pengaruh Kepuasan Kerja Terhadap Employee Engagement Teller Di Pt. Bank Negara Indonesia Cabang Bandung (Doctoral Dissertation, Universitas Widyatama). 
[15]. Lai, P.Y., Lee, J.S., Lim, Y.X., Yeoh, R.G., dan Mohsin, F.H (2015) The Linkage between Training and Development and Co-Worker Support towards Employee Engagement in Hotel Industry. International Journal of Scientific and Research Publications, Volume 5, Issue 5, May 2015.

[16]. Lolowang, M. G., Adolfina, A., \& Lumintang, G. (2016). Pengaruh Pelatihan dan Pengembangan Sumber Daya Manusia terhadap Kinerja Karyawan pada Pt. Berlian Kharisma Pasifik Manado. Jurnal EMBA: Jurnal Riset Ekonomi, Manajemen, Bisnis dan Akuntansi, 4(2).

[17]. Macey, W.H. \& Schneider, B. (2008). The Meaning of Employee Engagement. Journal of Industrial and Organizational Psychology, 1(1), 3-30.

[18]. Mangundjaya, W. L. (2012). Persepsi Dukungan Organisasi Versus Kepuasan Kerja Dan Perannya Terhadap Perilaku Kewarganegaraan Organisasi. Jurnal Psikologi Undip, 11(2), 9.

[19]. Markos, S., \& Sridevi, M. S. (2010). Employee engagement: The key to improving performance. International Journal of Business and Management, 5(12).

[20]. Mathis, Robert L. dan Jackson John H. 2010. Human Resource Management. Edisi Tigabelas, USA: SouthWestern, Cengage Learning.

[21]. Mondy, R. Wayne. 2008. Human Resource Management. Di alih Bahasa oleh Bayu Airlangga, M.M. Edisi kesepuluh. PT Gelora Aksara Pratama

[22]. Nicholas, A. J. (2009). Generational perceptions: Workers and consumers. Journal of Business \& Economics Research (JBER), 7(10).

[23]. Park, J., \& Gursoy, D. (2011). Generation effect on the relationship between work engagement, satisfaction, and turnover intention among US hotel employees.

[24]. Pratiwi, K., \& Himam, F. (2014). Kualitas Kehidupan Kerja Ditinjau Dari Kepuasan Kerja Dan Persepsi Terhadap Kinerja. Jurnal Psikologi Undip, 13(1).

[25]. Purnami, R., S. (2019). Peningkatan Employee Engagement Melalui Peran Kepemimpinan, Spiritualitas Di Tempat Kerja Dan Penciptaan Lingkungan Kerja. Prosiding FRIMA (Festival Riset Ilmiah Manajemen dan Akuntansi), (2), 609-614.

[26]. Robbins, S. P., \& Judge, T. A. (2015). Perilaku Organisasi Edisi 16.

[27]. Robertson-Smith, G., \& Markwick, C. (2009). Employee engagement: A review of current thinking. Brighton: Institute for Employment Studies.

[28]. Robinson, D., Perryman, S., \& Hayday, S. (2004). The drivers of employee engagement. Report-Institute for Employment Studies.

[29]. Saks, A. M. (2006). Antecedents and consequences of employee engagement. Journal of managerial psychology, 21(7).

[30]. Sari, O. R., \& Susilo, H. (2018). Pengaruh Kepuasan Kerja Terhadap Kinerja Karyawan Dengan Organizational Citizenship Behavior Sebagai Variabel Intervening (Studi Pada Karyawan Ptpn X-Unit Usaha Pabrik Gula Modjopanggoong Tulungagung). Jurnal Administrasi Bisnis, 64(1), 28-35.
[31]. Schaufeli, W. B., \& Bakker, A. B. (2004). Job demands, job resources, and their relationship with burnout and engagement: A multi-sample study. Journal of organizational Behavior, 25(3).

[32]. Schmitt, Bernd. (2011). Experience Marketing: Concepts, Frameworks and Consumer Insights. Foundations and Trend in Marketing, 5(2)

[33]. Siddhanta, A. \& Roy, D. (2010). Employee Engagement - Engaging the 21st Century Workforce. Asian Journal Management Research.

[34]. Sonnentag, S. \& Frese, M. (2001). Performance Concept and Performance Theory. Psychological Managemenet of Individual performance.

[35]. Spector, P. E. (1997). Job satisfaction: Application, assessment, causes, and consequences (Vol. 3). Sage publications.

[36]. Sulaefi, S. (2017). Pengaruh Pelatihan Dan Pengembangan Terhadap Disiplin Kerja Dan Kinerja Karyawan. Jurnal Manajemen Dan Kewirausahaan, 5(1).

[37]. Vazirani, N. (2007). Employee engagement. SIES College of Management Studies, Working Paper Series. 